\title{
EFFECTS OF SUBSTITUTION OF FISH MEAL WITH FRESH AND DEHYDRATED LARVAE OF THE HOUSE FLY (Musca domestica L) ON PRODUCTIVE PERFORMANCE AND HEALTH OF BROILERS
}

ĐORĐEVIĆ M*, RADENKOVIĆ-DAMNJANOVIĆ BRANA*, VUČINIĆ MARIJANA*, BALTIĆ $M^{*}$ TEODOROVIĆ RADISLAVA*, JANKOVIĆ LJILJANA*, VUKAŠINOVIĆ MARIJA** and RAJKOVIĆ M**

*Faculty of Veterinary Medicine, University of Belgrade, Serbia

**Specialized Veterinary Institute, Kraljevo, Serbia

(Received 14. February 2008)

In order to investigate the effects of substitution of fish meal with fresh and dried housefly larvae (Musca domestica L) on productive performance and health status of broilers a study was conducted on a poultry farm in the vicinity of Belgrade.

Two hundred Hybro-G broilers, of both sexes, originating from the same parent flock, of standardized body mass, were divided into four equal experimental groups. The experiment lasted 42 days. The control group (C) was fed standard diets. The broilers of the first and second experimental groups (O-I and O-II) were fed diets in which $50 \%$, and $100 \%$, fish meal had been substituted with housefly larvae meal (HLM). The third experimental group (O-III) was fed diets without fish meal, but supplemented with no fresh larvae in special feeders.

The chemical analysis showed that dehydrated HLM contained $59.48 \%$ dry matter (DM) protein; whereas fresh larvae, prepared by a special technological method, contained $59.10 \%$ DM protein; whereas fish meal contained $67.39 \%$ DM protein.

Viewed in total, the obtained productive results for the experimental groups (O-I, O-II, O-III) were approximately the same as those for the control group (C); whereas the results obtained per phase show statistically significant differences, due to the influence of the applied treatments $(p<0.05 ; p<0.01)$.

The fresh and dehydrated larvae, used as substitutes for fish meal, had a positive effect on productive performance and health status of broilers, which provides a good possibility for using them in diets intended for feeding broilers.

Key words: broilers, fresh larvae, dehydrated housefly larvae, productive performance 


\section{INTRODUCTION}

High cost of feedstuffs used in poultry nutrition, mostly imported ones, poses a serious problem to modern poultry farming that has to be solved in order to ensure in the future alternative feedstuffs as protein sources, that, at the same time, should qualitatively satisfy poultry needs and would cost less than the imported ones. One such possibility is the use of housefly larvae (Musca domestica $L$ ). Controlled rearing of houseflies implies processing of fresh manure wastes from poultry and pig farms, while using different developmental stages of the housefly (Musca domestica L). Biohumus and housefly larvae (in the form of biomass) are obtained as an end product of this procedure. The majority of the available references stress ecological advances of such a technological procedure, biohumus being a quality organic fertilizer (Calvert et al., 1969, 1970). Only few researches point to the possibility of using housefly larvae in animal nutrition, especially that of poultry and fish.

Chemical analyses showed that dehydrated housefly larvae contained $60 \%$ crude protein and $20 \%$ crude fat; the aminoacid content of proteins being similar to that of fish meal (Inaoka et al., 1999). Awoniyi et al. (2003) reported that HLM contains $92.6 \%$ dry matter, $55.1 \%$ crude protein, $20.7 \%$ crude fat, $10.4 \%$ ash and $6.3 \%$ cellulose.

Previous investigations have shown that housefly larvae, in the fresh form and in meal form, can substitute fish meal in broiler diets; this replacement resulting in optimal productive performance, without any harmful impact on broilers' health (Luo, 1989; Cohle et al., 2001; Cockerum, 2001, Fasakin et al., 2003).

Awoniyi et al. (1999, 2003, 2004) and Atteh (1993, 1994) performed experiments with three-week old animals. The broilers were fed diets where $25 \%$, $50 \%, 75 \%$ or $100 \%$ of fish meal had been substituted with HLM. This HLM contained $55.1 \%$ protein and $20.7 \%$ fat. The obtained results showed that, during the first six weeks, the experimental animals exhibited no differences in body mass, feed consumption and feed conversion; whereas, during the period from the sixth until the ninth week of the experiment, the same monitored parameters were under the influence of the applied treatments.

All this prompted us to undertake an investigation of the quality of housefly larvae (Musca domestica L) as a possible source of proteins, as well as their impact on productive performance and health state of broilers.

\section{MATERIAL AND METHODS}

The experiment comprised 200 Hybro-G broilers, aged 1-42 days. One-day old chicks were divided into four groups: the control group (C), fed a standard diet; the first experimental group (0-I), fed a diet in which $50 \%$ of fish meal had been substituted with HLM; the second experimental group (0-II), fed a diet in which $100 \%$ of fish meal had been substituted with HLM, and the third experimental group (0-III) fed a diet with no fish meal, but supplemented with washed fresh housefly larvae placed in special feeders. All the groups were fed ad 
Acta Veterinaria (Beograd), Vol. 58. No. 4, 357-368, 2008.

Đorđević $\mathrm{M}$ et al.: Effects of substitution of fish meal with fresh and dehydrated larvae

of the house fly (Musca domestica $L$ ) on productive performance and health of broilers

libitum. Each group consisted of 50 broilers, with the same number of females and males, and of standardized body mass $(40.55 \pm 0.34 \mathrm{~g})$.

The experiment lasted 42 days, and was conducted in three phases: the first phase (days 1-21), the second phase (days 22-35), and the third phase (days 3642). After the termination of each experimental phase the following parameters were checked: body mass, weight gain, feed consumption and food conversion. The animals' health and mortality rate were monitored throughout the experiment.

Housefly larvae were produced under controlled conditions, on fresh poultry manure derived from the hen layers farm in Batajnica, small village near Belgrade. Prior to the experiment, all fresh larvae were washed for $15 \mathrm{~min}\left(40^{\circ} \mathrm{C}\right)$ with warm, microbiologically and hygienically safe water. The washed larvae were then dried according to the method of Fasakin (2003).

The chemical composition of fresh and dehydrated housefly larvae, and of fish meal, was assessed using the standard methods (AOAC, 2002) and is presented in Table 1.

Table 1. Chemical composition of housefly larvae and fish meal

\begin{tabular}{|l|c|c|c|}
\hline \multirow{2}{*}{$\begin{array}{l}\text { Chemical } \\
\text { composition }\end{array}$} & Fresh larvae & Dried larvae & Fish meal \\
\cline { 2 - 4 } & 11.53 & 14.24 & 19.57 \\
\hline \hline Ash & 59.10 & 59.48 & 67.39 \\
\hline Protein & 13.92 & 11.53 & 0.65 \\
\hline Fibre & 4.05 & 6.66 & 7.17 \\
\hline Fat & 11.49 & 8.08 & 5.22 \\
\hline 2NFE & 13.42 & 13.77 & 14.18 \\
\hline 3ME, MJ/kg & 3.62 & 5.96 & 7.28 \\
\hline Ca & 1.95 & 1.05 & 3.48 \\
\hline P & 4.43 & 4.41 & 5.11 \\
\hline Lysine & 1.53 & 1.50 & 1.96 \\
\hline Methionine & 0.43 & 0.46 & 0.65 \\
\hline Cystine & 100.00 & 100.00 & 100.00 \\
\hline Total & & & \multicolumn{3}{|c|}{} \\
\hline
\end{tabular}

${ }^{1}$ DM-dry matter; ${ }^{2}$ NFE nitrogen free extract; ${ }^{3}$ ME-metabolic energy

Broilers were fed diets with the following ingredients and chemical composition (Tables 2 and 3). 


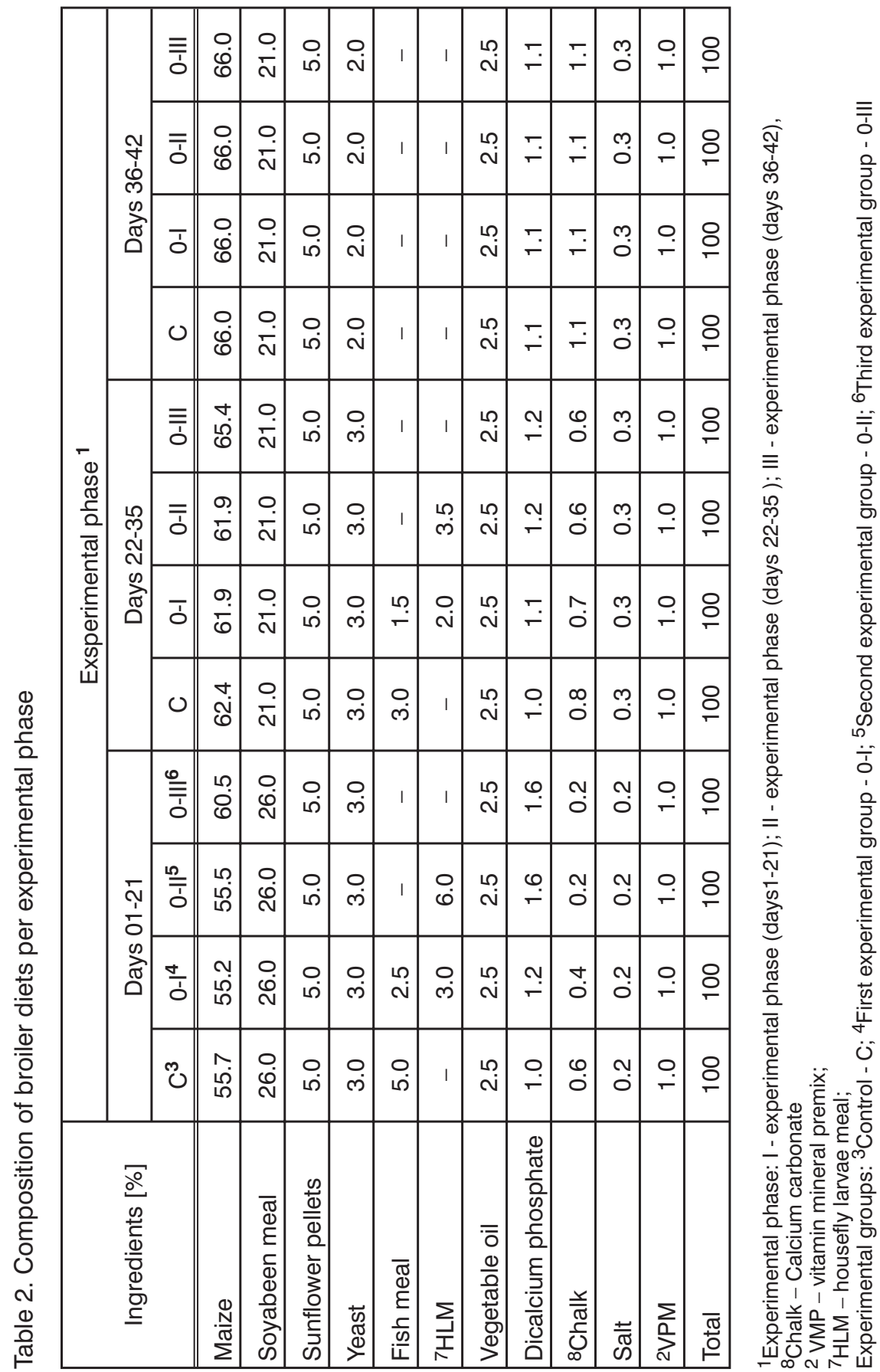


Acta Veterinaria (Beograd), Vol. 58. No. 4, 357-368, 2008.

Đorđević $\mathrm{M}$ et al.: Effects of substitution of fish meal with fresh and dehydrated larvae

of the house fly (Musca domestica $L$ ) on productive performance and health of broilers

Table 3. Chemical composition of feed mixes for broilers per experimental phases

\begin{tabular}{|c|c|c|c|c|c|}
\hline \multirow{2}{*}{$\begin{array}{l}\text { Chemical } \\
\text { composition }\end{array}$} & \multicolumn{5}{|c|}{$\%$ ingredients per experimental groups and experimental phase } \\
\hline & $\begin{array}{l}\text { Experimental } \\
\text { phase }\end{array}$ & $\mathrm{C}$ & O-I & $\mathrm{O}-\mathrm{II}$ & O-III \\
\hline \multirow{3}{*}{ Moisture } & $01-21$ & 11.11 & 11.08 & 11.03 & 11.34 \\
\hline & $22-35$ & 11.33 & 11.30 & 11.30 & 11.48 \\
\hline & $36-42$ & 11.50 & 11.50 & 11.50 & 11.50 \\
\hline \multirow{3}{*}{ Ash } & $01-21$ & 5.40 & 5.34 & 5.47 & 4.75 \\
\hline & $22-35$ & 5.13 & 5.12 & 5.04 & 4.63 \\
\hline & $36-42$ & 4.94 & 4.94 & 4.94 & 4.94 \\
\hline \multirow{3}{*}{$\begin{array}{l}\text { Crude } \\
\text { protein }\end{array}$} & $01-21$ & 22.21 & 22.26 & 22.30 & 19.49 \\
\hline & $22-35$ & 19.30 & 19.43 & 19.32 & 17.68 \\
\hline & $36-42$ & 17.25 & 17.25 & 17.25 & 17.25 \\
\hline \multirow{3}{*}{$\begin{array}{l}\text { Crude } \\
\text { fat }\end{array}$} & $01-21$ & 5.48 & 5.47 & 5.47 & 5.34 \\
\hline & $22-35$ & 5.56 & 5.57 & 5.56 & 5.48 \\
\hline & $36-42$ & 5.49 & 5.49 & 5.49 & 5.49 \\
\hline \multirow{3}{*}{$\begin{array}{l}\text { Crude } \\
\text { fibre }\end{array}$} & $01-21$ & 4.02 & 4.31 & 4.60 & 4.09 \\
\hline & 22-35 & 3.86 & 4.05 & 4.20 & 3.90 \\
\hline & $36-42$ & 3.89 & 3.89 & 3.89 & 3.89 \\
\hline \multirow{3}{*}{ NFE } & $01-21$ & 52.79 & 51.53 & 51.13 & 54.99 \\
\hline & $22-35$ & 54.82 & 54.54 & 54.58 & 56.83 \\
\hline & $36-42$ & 56.94 & 56.94 & 56.94 & 56.94 \\
\hline \multirow{3}{*}{$\mathrm{Ca}$} & $01-21$ & 1.00 & 0.98 & 1.02 & 0.69 \\
\hline & $22-35$ & 0.91 & 0.92 & 0.89 & 0.70 \\
\hline & $36-42$ & 0.85 & 0.85 & 0.85 & 0.85 \\
\hline \multirow{3}{*}{$P$} & $01-21$ & 0.77 & 0.75 & 0.76 & 0.72 \\
\hline & $22-35$ & 0.69 & 0.68 & 0.66 & 0.64 \\
\hline & $36-42$ & 0.61 & 0.61 & 0.61 & 0.61 \\
\hline \multirow{3}{*}{$\mathrm{ME} / \mathrm{MJ} / \mathrm{kg}$} & $01-21$ & 12.98 & 12.98 & 12.33 & 13.07 \\
\hline & $22-35$ & 13.19 & 12.98 & 12.83 & 13.26 \\
\hline & $36-42$ & 13,25 & 13.25 & 13.25 & 13.25 \\
\hline \multirow{3}{*}{ Lisine } & $01-21$ & 1.31 & 1.30 & 1.29 & 1.06 \\
\hline & $22-35$ & 1.31 & 1.30 & 1.29 & 1.06 \\
\hline & $36-42$ & 0.88 & 0.88 & 0.88 & 0.88 \\
\hline \multirow{3}{*}{$\begin{array}{l}\text { Methionine+ } \\
\text { Cystine }\end{array}$} & $01-21$ & 0.70 & 0.69 & 0.68 & 0.59 \\
\hline & $22-35$ & 0.70 & 0.69 & 0.68 & 0.59 \\
\hline & $36-42$ & 0.53 & 0.53 & 0.53 & 0.53 \\
\hline \multirow{3}{*}{ Total } & $01-21$ & \multirow{3}{*}{100.0} & \multirow{3}{*}{100.0} & \multirow{3}{*}{100.0} & \multirow{3}{*}{100.0} \\
\hline & $22-35$ & & & & \\
\hline & $36-42$ & & & & \\
\hline
\end{tabular}


The results are expressed as a mean $\pm \mathrm{SD}$. One-way analysis of variance (ANOVA) was applied for differences between groups of broilers. When the ANOVA results were significant, Tukey HSD-test was used to determine the level of significance. All computations were performed using the statistical software package VassarStats (Lowry Richard, 1998-2007, Vassar College, US).

\section{RESULTS}

Productive performance is presented in Tables 4, 5, 6 and 7.

Table 4 contains the results which refer to the body mass of broilers. The highest body mass, at the end of the experiment, was measured in the group fed diets without fish meal, but supplemented with fresh larvae in special feeders (0III), reaching $1734.29 \pm 197.40 \mathrm{~g}$. This value was significantly different $(p<0.01)$ from the lowest body mass of $1597.08 \pm 194.98 \mathrm{~g}$. in broilers fed diets in which $50 \%$ of fish meal had been supplemented with HLM (0-I). The Table shows statistically significant differences between groups per experimental phase.

Table 4. Broilers' body mass during the experiment [g]

\begin{tabular}{|c|c|c|c|c|}
\hline \multirow{2}{*}{$\begin{array}{c}\text { Day of } \\
\text { experiment }\end{array}$} & \multicolumn{4}{|c|}{ Experimental group } \\
\hline & C & ו-0 & $0-I I$ & $0-1 I I$ \\
\hline Day 01 & $40.51 \pm 0.36$ & $40.60 \pm 0.34$ & $40.48 \pm \quad 0.34$ & $40.60 \pm \quad 0.34$ \\
\hline Day 21 & $\mathrm{AB}_{618.44 \pm 92.63}$ & $\mathrm{AC}_{657.34 \pm 72.57}$ & $\mathrm{BD}_{664.20 \pm 87.42}$ & $\mathrm{CD}_{734.50 \pm 101.11}$ \\
\hline Day 35 & $\mathrm{~A}_{1298.57 \pm 58.69}$ & 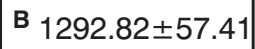 & $\mid c_{1304.35 \pm 48.19}$ & $\mathrm{ABC}_{1352.24 \pm 108.47}$ \\
\hline Day 42 & $1638.88 \pm 187.62$ & $1597.08 \pm 194.98$ & $1646.67 \pm 199.82$ & $\mathrm{~A}_{1734.29 \pm 197.40}$ \\
\hline
\end{tabular}

${ }^{1}$ Value expressed in grams as $\mathrm{X} \pm \mathrm{S}_{\mathbf{d}}$

Small letters a,b,c,d,e,f $p<0.05$; Capital letters A,B,C,D,E,F $p<0.01$

Statistical significances between groups are given per days (rows in tables)

Table 5 shows the broilers' growth gain. The highest growth gain is achieved in the group fed diets without fish meal, but supplemented with fresh larvae in special feeders (0-III), being $40.33 \pm 4.69 \mathrm{~g}$. The lowest growth gain was ascertained in the group fed diets in which $50 \%$ of fish meal had been supplemented with HLM (0-I), being $37.06 \pm 4.63 \mathrm{~g}$. At the end of the experiment (Day 42) there was a statistically significant difference between the highest and lowest growth gain values.

Table 6 contains the results relative to the mean daily feed intake. The highest value of $75.71 \mathrm{~g}$ was noticed in the broilers fed diets without fish meal, but supplemented with fresh housefly larvae in special feeders (0-III). The lowest value of the mean daily feed consumption of $68.66 \mathrm{~g}$. was observed in broilers fed diets in which $50 \%$ of fish meal had been substituted with HLM (0-I). The third group of broilers (0-III), during the period from Day 1 to Day 35 of the experiment, 
Acta Veterinaria (Beograd), Vol. 58. No. 4, 357-368, 2008.

Đorđević $\mathrm{M}$ et al.: Effects of substitution of fish meal with fresh and dehydrated larvae of the house fly (Musca domestica $L$ ) on productive performance and health of broilers

in addition to the standard diets, ingested on the average $23 \mathrm{~g} /$ day of fresh housefly larvae.

Table 5. Weight gain ${ }^{1}$ during the experiment, [g]

\begin{tabular}{||c|r|r|r|r||}
\hline \multirow{2}{*}{$\begin{array}{c}\text { Phase of } \\
\text { experiment }\end{array}$} & \multicolumn{4}{|c||}{ Experimental group } \\
\cline { 2 - 5 } & $\mathrm{C}$ & $0-\mathrm{I}$ & \multicolumn{1}{c||}{ 0-II } & \multicolumn{1}{c|}{ 0-III } \\
\hline \hline $01-21$ & $\mathrm{~A}_{27.52 \pm 4.39}$ & $\mathrm{~B}_{29.37 \pm 3.44}$ & $\mathrm{C}_{29.70 \pm 4.15}$ & $\mathrm{ABC}_{33.04 \pm 4.80}$ \\
\hline $22-35$ & $\mathrm{ABC}_{48.78 \pm 3.23}$ & $\mathrm{~A}_{45.53 \pm 2.15}$ & $\mathrm{aB}_{45.90 \pm 3.52}$ & $\mathrm{aC}_{44.12 \pm 4.02}$ \\
\hline $36-42$ & $48.62 \pm 18.71$ & $\mathrm{a}_{43.74 \pm 20.99}$ & $49.26 \pm 23.22$ & $\mathrm{a}_{55.59 \pm 16.21}$ \\
\hline $01-42$ & $38.06 \pm 4.46$ & $\mathrm{a}_{37.06 \pm 4.63}$ & $38.24 \pm 4.75$ & $\mathrm{a}_{40.33 \pm 4.69}$ \\
\hline
\end{tabular}

${ }^{1}$ Value expressed in grams as $\mathrm{X} \pm \mathrm{S}_{\mathbf{d}}$

Small letters $a, b, c, d, e, f p<0.05$; Capital letters A,B,C,D,E,F $p<0.01$

Statistical significances between groups are given per phase experiment (rows in tables)

Table 6. Daily feed intake during the experiment, [g]

\begin{tabular}{|c|c|c|c|c|}
\hline \multirow{2}{*}{$\begin{array}{l}\text { Experimental } \\
\text { group }\end{array}$} & \multicolumn{4}{|c|}{ Experimental phase } \\
\hline & $\begin{array}{r}01-21 \\
\text { index }\end{array}$ & $\begin{array}{r}22-35 \\
\text { index }\end{array}$ & $\begin{array}{r}36-42 \\
\text { index }\end{array}$ & $\begin{array}{r}01-42 \text { index } \\
\end{array}$ \\
\hline C & $\begin{array}{l}40.95 \\
100.00\end{array}$ & $\begin{array}{r}91.42 \\
100.00\end{array}$ & $\begin{array}{r}134.28 \\
100.00\end{array}$ & $\begin{array}{r}73.33 \\
100.00\end{array}$ \\
\hline O-I & $\begin{array}{r}43.80 \\
106.96\end{array}$ & $\begin{array}{r}85.42 \\
93.44\end{array}$ & $\begin{array}{r}109.91 \\
81.85\end{array}$ & $\begin{array}{r}68.66 \\
93.63\end{array}$ \\
\hline O-II & $\begin{array}{l}43.33 \\
105.81\end{array}$ & $\begin{array}{r}91.14 \\
99.69\end{array}$ & $\begin{array}{l}137.14 \\
102.13\end{array}$ & $\begin{array}{l}74.90 \\
102.14\end{array}$ \\
\hline O-III & $\begin{array}{l}48.00 \\
\quad 117.22\end{array}$ & $\begin{array}{l}90.88 \\
99.41\end{array}$ & $\begin{array}{r}129.71 \\
96.60\end{array}$ & $\begin{array}{l}75.71 \\
\quad 103.25\end{array}$ \\
\hline
\end{tabular}

Table 7 contains the results which refer to food conversion. The best conversion, leaving out consumption of fresh larvae, was ascertained in the group fed diets in which $50 \%$ of fish meal had been substituted with HLM (0-I), being $1850.0 \mathrm{~g}$.

The mortality rate of broilers during the experiment remained within technological standards for Hybro G broilers (Hybro, 1997). The highest mortality rate, at the end of the experiment, was reported in the broilers fed diets in which $50 \%$ of fish meal had been substituted with HLM (0-I), and in the broilers fed diets in which $100 \%$ of fish meal had been substituted with HLM (0-I), being $4 \%$; whereas, the mortality rate in the control group $(\mathrm{C})$, fed diets with no fish meal, but supplemented with fresh housefly larvae in special feeders (0-III), was $2 \%$. 
Acta Veterinaria (Beograd), Vol. 58. No. 4, 357-368, 2008.

Đorđević $\mathrm{M}$ et al.: Effects of substitution of fish meal with fresh and dehydrated larvae of the house fly (Musca domestica L) on productive performance and health of broilers

Table 7. Feed conversion during the experiment, $[\mathrm{kg}]$

\begin{tabular}{|c|c|c|c|c|}
\hline \multirow{2}{*}{$\begin{array}{l}\text { Experimental } \\
\text { group }\end{array}$} & \multicolumn{4}{|c|}{ Experimental phase } \\
\hline & $\begin{array}{l}01-21 \\
\text { index }\end{array}$ & $\begin{array}{l}22-35 \\
\text { index }\end{array}$ & $\begin{array}{l}36-42 \\
\text { index }\end{array}$ & $\begin{array}{r}01-42 \\
\text { index }\end{array}$ \\
\hline C & $\begin{array}{r}1.48 \\
100.00\end{array}$ & $\begin{array}{l}1.87 \\
100.00\end{array}$ & $\begin{array}{l}2.76 \\
100.00\end{array}$ & $\begin{array}{l}1.93 \\
100.00\end{array}$ \\
\hline O-I & $\begin{array}{l}1.49 \\
100.68\end{array}$ & $\begin{array}{l}1.87 \\
100.00\end{array}$ & $\begin{array}{l}2.50 \\
90.58\end{array}$ & $\begin{array}{l}1.85 \\
95.85\end{array}$ \\
\hline O-II & $\begin{array}{r}1.45 \\
97.97\end{array}$ & $\begin{array}{l}1.98 \\
105.88\end{array}$ & $\begin{array}{l}2.78 \\
100.72\end{array}$ & $\begin{array}{l}1.96 \\
101.55\end{array}$ \\
\hline O-III & $\begin{array}{l}1.45 \\
97.97\end{array}$ & $\begin{array}{l}2.04 \\
109.09\end{array}$ & 2.33 & ${ }^{1.88} 97.41$ \\
\hline
\end{tabular}

\section{DISCUSSION}

The chemical composition, i.e. the nutritive value, represents the basic parameter that can point to the utilization level of some feedstuff in animal nutrition. The chemical composition of fresh housefly larvae is characterized by a high water content, relatively high protein content and low contents of the remaining feed ingredients. The obtained results of the chemical analysis of fresh larvae are mostly consistent with the data of Chana et al. (1999), who established that DM in fresh housefly larvae contained $56.5 \%$ crude protein. However, there is a marked difference between our results and those of the afore mentioned authors with regard to fat content. The fat content of fresh larvae in our experiment is lower (4.05\%) than the content reported by other authors (17.2-20.0\%). According to Atteh and Ologbenia (1993), the fat and proteins contents in fresh larvae are dependent on the larval stage; the protein content decreasing and the fat content increasing with the approach of the pupal stage.

The available literature contains abundant data with regard to the nutritive value of HLM, as, in such a form, larvae are more suitable for industrial production of mixes. The obtained results refering to the protein content in dehydrated HLM (59.48 \% in DM) are consistent with the results of Awoniyi et al. (2003) and Inaoka et al. (1999) - being 55.1-60.00\%. The protein content in dehydrated HLM depends on the larval stage and technological process of drying (Balogun et al., 1996; Balogun et al.,1997; Fasakin et al., 2003). The applied technological process affects the crude protein content in HLM- from $43.3 \%$ for full-fat meal dried in the sun to $46.7 \%$ hydrolized defatted oven dried meal. The obtained results are, with regard to the protein content, in agreement with the results of Inaoka et al. (1999); whereas the results for the protein content obtained by Fasakin et al. are somewhat lower (43.30-45.75\%). As for the fat content, during our experiment, we observed that fresh housefly larvae (4.05\%) and dried housefly larvae (6.66\%) had approximately the same fat content in dehydrated meal in comparison to the results of Fasakin et al. (2003), who reported that the fat 
Acta Veterinaria (Beograd), Vol. 58. No. 4, 357-368, 2008.

content in dehydrated meal ranged from $6.28 \%$ to $13.65 \%$, depending on the applied technological procedure.

The relation and quantity of individual feedstuffs in diets intended for feeding experimental broilers are formulated in the standard way. The results of the analyses of the chemical composition of the diets fed to the control group show that they, throughout the experiment, satisfied the technological standards for Hybro $G$ broilers (Hybro,1997), i.e. the content of ingredients was consistent with the broilers' requirements in different feeding phases (NRC, 1994). The chemical composition and the amino acid content of diets intended for broilers of the experimental groups (0-I and $0-\mathrm{II})$, where the isoprotein substitution of fish meal with HLM has been made, did not differ from the chemical composition of the diets for the control group (C). As for the third group (0-III), somewhat lower contents of protein and amino acids are noticeable, as these diets did not contain either fish meal or HLM, and housefly larvae were supplied in a fresh form, ad libitum, in special feeders. In conclusion, the chemical composition of mixes in our experiment was such that, on one hand, it satisfied broilers' requirements, and, on the other hand, was consistent with the requirements planned prior to the beginning of the experiment.

The body mass of broilers in all experimental groups was standardized at the beginning of the experiment, numerical differences being not significant. The obtained results with regard to body mass, fully justify the possibility of using housefly larvae, in various forms, as a substitute for fish meal, and are consistent with the results of Cohle et al. (2001), Cockerum (2001), and Fasakin et al. (2003).

Compared to body mass, the daily weight gain is a more reliable indicator of feed quality. Viewed as a whole, with the replacement of fish meal with HLM, almost identical weight gain is achieved as in the case of fish meal-based diets; the result being consistent with the findings reported by the majority of authors (Atteh, 1993,1994; Awoniyi et al., 1999, 2003, 2004; Inaoka, 1999; Teguia, 2002). However, the supplement of fresh housefly larvae to diets without fish meal has positive effects on the monitored parameters.

The use of diets where fish meal was substituted with HLM, as well as the use of diets without fish meal, but supplemented with fresh housefly larvae in special feeders, had no special effects on feed intake. The results obtained for the consumption of diets where fish meal had been substituted with dehydrated HLM (Musca domestica $L$ ) are identical to the results of other authors (Atteh, 1993, 1994; Awoniyi et al., 1999, 2003, 2004; Inaoka, 1999; Teguia, 2002), which proves that the performed substitution has no adverse effect on broilers' feed intake, i.e it is possible to substitute fish meal with HLM, if economically justifiable. It has to be stressed that the 0-III group had the highest feed intake. The broilers of the experimental groups willingly consumed the offered diets and fresh larvae from special feeders. Data on similar experiments (Cilevski, 1994) show that broilers willingly consume fresh housefly larvae, this probably has to do with their physiological and biological characteristics as birds.

Food conversion, as an interaction of weight gain and food consumption, is obviously the best indicator of feed quality and its possibility to satisfy specific needs of young growing animals. The food conversion in the broilers' control 
group (C), fed standard diets, remained within limits of the expected technological standards for Hybro G broilers (Hybro, 1997). The substitution of fish meal with dehydrated HLM, too, has no negative effects on food conversion in 0-I, 0-II and 0III experimental groups, which points that it is possible to substitute fish meal with fresh dried housefly larvae (Musca domestica L). Similar conclusions are reported by Teguia (2002) and Awoniyi et al. (2003).

\section{CONCLUSION}

On the basis of the obtained results for the performed experiment, the following conclusions can be reached:

The chemical composition of fresh housefly larvae shows a high water content (79.02), a relatively high protein content (59.10 in DM), and a small amount of other ingredients.

HLM is characterized by high protein content ( $59.48 \% \mathrm{DM})$, with satisfactory contents of lysine, methionine and cystine, and a low fat content $(6.66 \% \mathrm{DM})$. The nutritive value of HLM is somewhat lower than that of fish meal $(67.39 \% \mathrm{DM})$.

The productive performance of the broilers fed diets with isoprotein substitution of fish meal with HLM was satisfactory.

Broilers willingly ingested fresh housefly larvae (Musca domestica L), and having in mind their high amino acid content, there is a justifiable possibility to use them in the nutrition of broilers reared under organic farming conditions.

In conclusion, the applied treatments did not have a negative impact on productive performance or health status of broilers, thus offering a real opportunity of replacing fish meal with fresh and dehydrated housefly larvae produced under controlled conditions.

Address for correspondence:

Milutin Đorđević, assistant professor

Faculty of Veterinary Medicine

Department of Animal Hygiene

Bul. oslobođenja 18, 11000 Belgrade

Serbia

E-mail:milutin@vet.bg.ac.yu

\section{REFERENCES}

1. AOAC, 2002, Official Methods of Analysis of AOAC International, 17th Edition, 2002.

2. Atteh JO, JO Oyedeji, 1994, The replacement value of maggots for groundnut cake in broiler, Centre point, 4, 39-46.

3. Atteh JO, Ologbenla S, 1993, Replacement of meal with maggot in broiler diets, Effects on performance and nutrition, Nig J Anim Prod, 20, 44-9.

4. Awoniyi TAM, Adebayo IA, Aletor VA, 2004, A study of Some Erythrocyte Indices and Bacteriological Analysis of Broiler-chickens Raised on Maggot-meal Based Diets, Int J Poult Sci , 3, 6, 386-90.

5. Awoniyi TAM, Aletor VA, Aina JM, 2003, Performance of Broiler - Chickens Fed on Maggot Meal in Place of Fishmeal, Int J Poult Sci 2, 4, 271-4.

6. Balogun AM, Fasakin EA, 1996, Flesh yield and aspects of chemical composition of flesh of some commercially important freshwater fish species in Nigeria, J Agricult Technol, 4, 33-40. 
Acta Veterinaria (Beograd), Vol. 58. No. 4, 357-368, 2008.

Đorđević $\mathrm{M}$ et al.: Effects of substitution of fish meal with fresh and dehydrated larvae

of the house fly (Musca domestica $L$ ) on productive performance and health of broilers

7. Balogun AM, Fasakin EA, Owolanske D, 1997, Evaluation of fish silage/soybean meal blends as protein feedstuff for Claris gariepinus (Burchell, 1822) fingerlings, J Agricult Technol, 4, 36-40.

8. Barnard $D R$, Harms $R H$, Sloan $D R$, 1998, Bio-degradation of poultry manure by house fly (Diptera:Muscidae), Environ Entomol, 2, 600-5.

9. Calvert CC, Martin RD, Morgan NO, 1969, House fly pupae as food for poultry, J Econ Entomol, 62 , 938-9.

10. Calvert CC, Morgan NO, Martin RD, 1970, House flylarvae: Biodegradation of hen excrete to useful products, Poultry Sci, 49, 588-9.

11. Cilevski A, 1994, Uticaj ishrane kalifornijskim kišnim glistama na proizvodne rezultate i zdravstveno stanje japanske prepelice (Coturnix coturnix japonica), Doktorska disertacija, Agronomski fakultet, Cačak.

12. Cockerum FL, 2001, The Finest Processed Avian \& Aguatic Insectile Diets, Trademark of Oregon Feeder Insects, Inc.

13. Fasakin EA, Balogun AM, Ajayi OO, 2003, Evaluation of full-fat and defatted maggot meals in the feeding of clarid catfish Clarias gariepinus fingerlings, Aquacult Res, 34, 9, 733-8.

14. Hopić S, 1999, Genetska i fenotipska varijabilnost kvantitativnih svojstava pilića u tovu, Doktorska disertacija, Poljoprivredni fakultet, Novi Sad.

15. Hopić S, Pavlovski Zlatica, Mašić B, 1993, Uporedno ispitivanje proizvodnih osobina brojlera različitih provenijenci 1991. godine, Biotehnologija u stočarstvu, 9, 25-32.

16. Hybro, 1997, Tehnološki podaci o brojlerima Hybro G, Nutreco Company.

17. Inaoka T, Okubo G, Yokota M, Takemasa M, 1999, Nutritive Value of House Fly Larvae and Pupae Fed on Chicken Feces as Food Source for Poultry, Jap poult Sci, 3, 36.

18. Khan B, Beck R, Goonwardene L, Hirsche W, 1999, A study on feeding house fly (Musca domestica) larva and pupa to fingerling trout (Onchrohhynchus mykiss), Livestock Insect Workers Conf, 3.

19. Kohle MS, Lewchuk K, Wolanski NJ, 2001, Larvae: Healthy for the environment, healthy for you, Poult Res Centre News, 10, 2.

20. Lowry R, 1998-2007, VassarStats: Web Site for Statistical Computation, Vassar College, US.

21. Luo Ke, 1989, The status of studies on feed insects in China, Dept of Plant Protection, Beijing Agricultural University, Kunchong Zhishi, 26,118-20.

22. National Research Council, 1993, Nutrient requirements for poultry, National Academy of Sciences, Washington D.C.

23. Teguia A, Mpoame M, Okourou Mba JA, 2002, The production performance of broiler birds as affected by the replacement of fish meal by maggot meal in the starter and finisher diets, Faculty of Agricuture and Agricultural Sciences, University of Dscahang, Cameroon, Faculty of Sciences, University of Dschang, Cameroon, Tropicultura, 20, 4,187-92. 


\title{
UTICAJ ZAMENE RIBLJEG BRAŠNA SVEŽIM I SUŠENIM LARVAMA DOMAĆE MUVE (Musca domestica L), NA PROIZVODNE REZULTATE I ZDRAVSTVENO STANJE BROJLERA
}

\author{
ĐORĐEVIĆ M, RADENKOVIĆ-DAMNJANOVIĆ BRANA, VUČINIĆ MARIJANA, BALTIĆ M, \\ TEODOROVIĆ RADISLAVA, JANKOVIĆ LJILJANA, VUKAŠINOVIĆ MARIJA \\ i RAJKOVIĆ M
}

\section{SADRŽAJ}

U cilju ispitivanja uticaja zamene ribljeg brašna svežim i sušenim larvama domaće muve (Musca domestica $L$ ) na proizvodne rezultate i zdravstveno stanje brojlera, sproveden je ogled ishrane u proizvodnjim uslovima, na živinarskoj farmi u okolini Beograda.

Dve stotine brojlera Hybro-G provinijence, poreklom od istog roditeljskog jata, oba pola i ujedanačene telesne mase, bilo je podeljeno u četiri jednake eksperimentalne grupe i hranjeno 42 dana. Za ishranu brojlera kontrolne grupe (K) korišćene su standardne smeše. Brojleri prve i druge ogledne grupe (0-I i 0-II) hranjeni su smešama u kojima je izvršena supstitucija ribljeg brašna (50 i 100\%) sa brašnom larvi domaće muve. Treća ogledna grupa brojlera (0-III) hranjena je smešama bez ribljeg brašna uz dodatak svežih larvi u posebnim hranilicama.

Hemijskom analizom je utvrđeno da dehidrovano brašno larvi domaće muve sadrži 59,48\% proteina u suvoj materiji (SM), a da sveže larve pripremljene po posebnom tehnološkom postupku sadrže $59.10 \%$ proteina u SM, dok je riblje brašno korišćeno u našem eksperimentu sadržalo $67.39 \%$ proteina u SM.

Dobijeni rezultati, posmatrano u celini, su ukazali da su ogledne grupe (0-I, 0-II i 0-III) postigle približno iste proizvodne rezulate kao kontrolna grupa (K), pri čemu dobijeni proizvodni rezultati po fazama ogleda pokazuju statistički značajne razlike pod uticajem primenjenih tretmana u toku svih faza ogleda $(p<0,05$; $p<0,01)$.

Sveže i sušene larve, koje su korišćene kao zamena za riblje brašno u ogledu ishrane ostvarile su pozitivan efekat na proizvodne rezultate i zdravstveno stanje, što pruža realnu mogućnost njihovog korišćenja u smešama za ishranu brojlera. 